Article

\title{
Investigating Visual Content Shared over Twitter during the 2019 EU Parliamentary Election Campaign
}

\author{
Nahema Marchal ${ }^{1, *}$, Lisa-Maria Neudert ${ }^{1}$, Bence Kollanyi ${ }^{2}$ and Philip N. Howard ${ }^{1}$ \\ ${ }^{1}$ Oxford Internet Institute, University of Oxford, Oxford, OX1 3JS, UK; E-Mails: nahema.marchal@oii.ox.ac.uk (N.M.), \\ lisa-maria.neudert@oii.ox.ac.uk (L.-M. N.), philip.howard@oii.ox.ac.uk (P.N.H.) \\ 2 Doctoral School of Sociology, Corvinus University of Budapest, 1093 Budapest, Hungary; \\ E-Mail: bence.kollanyi@stud.uni-corvinus.hu \\ * Corresponding author
}

Submitted: 30 June 2020 | Accepted: 1 September 2020 | Published: 3 February 2021

\begin{abstract}
Political communication increasingly takes on visual forms. Yet, despite their ubiquity in everyday communication and digital campaigning, the use of these visuals remains critically understudied. In this article, we investigate the formats and modes of visual content deployed by Twitter users over a two-week period leading up to the 2019 EU Parliamentary elections and across two publics: those discussing the election at large and those discussing the more contentious issue of EU membership. Conducting a multilingual, cross-comparative content and thematic analysis of a sample of 1,097 images, we find that: (1) Visuals originating from traditional political actors prevailed among both Twitter discourses; (2) users shared substantial amounts of anti-EU, populist and, to a lesser extent, extremist images, though this content remained largely disjointed from the mainstream public debate; and (3) political humor emerged as a vector for anti-establishment and Eurosceptic themes, especially in discussions critical of the European project. We discuss the implications of our findings for the study of visual political communication and social media manipulation.
\end{abstract}

\section{Keywords}

elections; European politics; populism; social media; visual communication

\section{Issue}

This article is part of the issue "Dark Participation in Online Communication: The World of the Wicked Web" edited by Thorsten Quandt (University of Münster, Germany).

(C) 2021 by the authors; licensee Cogitatio (Lisbon, Portugal). This article is licensed under a Creative Commons Attribution 4.0 International License (CC BY).

\section{Introduction}

We live in an age of visual communication: From the rise of selfies, memes and animated GIFs in digital culture to the surging popularity of visual-centric platforms like Instagram, Snapchat, and TikTok that reach billions of monthly users across the world. Visual content in the form of photos, videos, infographics and user-generated images are becoming central to our day-to-day interactions online, informing how we present ourselves (Senft \& Baym, 2015; Thomson \& Greenwood, 2020), communicate and understand the world around us (Highfield \& Leaver, 2016; Pearce et al., 2020). Image sharing has recently seen a surge in popularity, not only on visual- centric platforms but also on Twitter, where over $50 \%$ of tweet impressions in 2019 were associated with images or other visual media (Meeker, 2019).

Visuals are also starting to take center stage in online political communication. While political parties and campaign managers have traditionally relied on leaflets, posters, and TV spots to rally support, the advent of digital technologies, and social media specifically, has seen political actors integrate new visual media strategies into their everyday communicative practices. Retouched Twitter profile pictures, vlogs from the campaign trail, Instagram livestreams, and staged photo ops capturing seemingly candid moments have now become staples of the arsenal of contemporary electioneering 
(Lilleker, Tenscher, \& Štětka, 2015). Technological affordances have also enabled completely novel forms of political self-expression among private citizens, from ballot selfies to Snapchat filters in support of specific causes (Gutterman, 2018).

In modern attention economies, visual forms of communication offer clear advantages over text; they are easier to process, elicit strong emotions and are effective at capturing viewers' attention and retention (Barry, 2005; Fahmy, Bock, \& Wanta, 2014; Newhagen, 1998). In recent years, however, they have also emerged as popular catalysts of misinformation and disinformation across Europe and worldwide, both through inadvertent amplification and as part of larger social media manipulation campaigns (Bradshaw \& Howard, 2019; Guy, 2017). The German Alternative für Deutschland (AfD) party, for example, has repeatedly used fake imagery involving immigrants relating to sexual abuse and violence to bolster anti-immigration sentiment during elections (Czuperski \& Nimmo, 2017). This is particularly concerning given that key research on this topic suggests that most individuals struggle to distinguish between real and manipulated images (Nightingale, Wade, \& Watson, 2017).

Despite their ubiquity in contemporary online political discourse, visuals have been somewhat neglected in the study of political communication, which overwhelmingly favors text-based approaches, especially in Europe (Weller, Bruns, Burgess, Mahrt, \& Puschmann, 2014). To address this oversight in this study, we conduct a multilingual, cross-case comparative content and thematic analysis of Twitter images posted by users in six different European language spheres-English, French, German, Italian, Spanish and Swedish-during a two-week-long period leading up to the 2019 EU Parliamentary elections. Specifically, we investigate images on Twitter in the context of two conversations: One surrounding the EU elections in general, and one surrounding the more contentious issue of membership to the EU. Three main research questions drive our analysis:

RQ1: What salient formats and modes of visual content were users in Europe sharing over Twitter during the 2019 EU Parliamentary election campaign?

RQ2: How does this differ across two conversations with varying degrees of contention?

RQ3: What were the most common themes embedded in different modes of visual communication?

In the following section, we begin by situating this research in the existing literature on visual media in political communication, their uses and effects. After detailing processes for data collection and sampling, we outline our coding scheme for analyzing the salient formats and modes of images shared over Twitter during the campaign, as well as their themes. We show that users shared substantial amounts of anti-European, pop- ulist and, to a lesser extent, extremist images, though these were largely disjointed from the mainstream public conversation. Our data also reveals political humor as a vessel for anti-establishment and Eurosceptic themes, especially in discussions critical of the European project. Furthermore, we find that while traditional visual formats dominate across both Twitter conversations, hybrid content in the form of memes, annotated screenshots and remixed media have also emerged as popular modes of visual communication. In the last section, we discuss these findings and their implications in the context of the 2019 European Parliamentary Elections and contemporary political communication more broadly.

\section{Literature}

\subsection{Visual Political Communication in Europe}

Digital modes of communication have been transformative for political communication. Through the continual expansion of networked infrastructures, social media platforms have emerged as arenas for the dissemination of political information to large audiences at marginal cost. Today, political actors rely on a wide array of such channels to engage with voters and other stakeholders year-round (Chadwick, 2013). Scholars underscore social media's vital role for advocacy (Karpf, 2012), e-governance (Margetts, John, Hale, \& Yasseri, 2015) and democratization (Howard \& Hussain, 2013). Non-party actors have also been shown to leverage social media to shape the political agenda, frame and amplify issues, and generate consensus among subsets of the electorate (Rohlinger, 2019).

Visual media has, in more ways than one, been at the heart of this transformation. While visual symbols themselves have long performed essential functions in political communication (Schill, 2012), the surging popularity of technologies whose affordances are specifically oriented towards the creation, dissemination and customization of images has awarded them newfound importance-especially times of heightened political tension such as electoral cycles. In Europe, both grassroots and mainstream political actors leverage visual formats as potent ways to communicate with their constituents and mobilize support. Cámara Castillo (2019, p. 49) demonstrates, for example, how European institutions carefully "advertise European identity" and foster civic interaction through immaculately curated Instagram feeds. In a departure from traditional forms of campaigning, 'satellite' and non-party intermediaries like Momentum, a British political organization, have also been credited with boosting support for Jeremy Corbyn's 2017 campaign through its clever use of memes, and short-form videos-tactics which were widely adopted by the political mainstream during the 2019 UK General Elections (Lyons, 2019).

Yet worryingly, digital platforms have also proven vulnerable to manipulation (Woolley \& Howard, 2018) 
and algorithmic gaming aimed at sowing discord in Europe and around the world (Jungherr, Posegga, \& An, 2019; Marchal, Kollanyi, Howard, \& Neudert, 2019). During recent elections in France, Germany, and Italy, for instance, hyper-partisan and conspiratorial junk news sites repeatedly outperformed professional news outlets on social media (Neudert, Howard, \& Kollanyi, 2019). Research also shows that xenophobic, national-populist, and other extreme-right 'movement-parties' (Kitschelt, 2006) make strategic use of digital media to spread Eurosceptic messages across publics (Caiani \& Pavan, 2017). A growing number of scholars note that hybrid visuals such as memes have become the format of choice to push political propaganda or troll social media users, often with the stated goal of driving division among key segments of the audience (Klein, 2019). Today, new digital visual media complement-if not altogether supplant-other, more traditional forms of political communication for party and non-party actors alike. To gain a better understanding of their formats and modes in the political context, in the next section we review existing literature on their uses on social media.

\subsection{The Political Uses of Social Media Visuals}

Visual media have diverse uses in digital political communication. With the widespread adoption of smartphones, social media users have been empowered to document and share real-time footage of political events in new forms of 'mobile witnessing' (Reading, 2011) and citizen journalism. Twitter, a micro-blogging platform favored by journalists, opinion leaders and politicians and geared towards opinion broadcasting (Marwick \& boyd, 2011) has emerged as a prime arena for political image sharing. Images shared over Twitter, for instance, formed an important part of both the 2011 Egyptian revolution (Kharroub \& Bas, 2015) and the 2012 Israel-Hamas conflict (Seo, 2014) as well as more recently during the 2020 Black Lives Matter protests.

Further, images are often shared as a means of interpersonal communication to express an opinion, persuade, or even manipulate. The adage that an image is worth a thousand words underscores the strong rhetorical impact that visuals have on those who view them (Birdsell \& Groarke, 2007). Research suggests that audiences process images faster and more efficiently than text alone (Graber, 2012). Typically, images tap into a larger socio-political context (Schill, 2012) and are often used in conjunction with or in response to other images and text to highlight specific aspects of an issue (Blair, 2004; de Vreese, 2005).

Decontextualized, altered or altogether fake images have also become prolific on social media, where they bypass traditional gatekeepers and often elude content moderators (Gillepsie, 2018). In a hybrid media ecosystem, a large amount of viral visual content takes the form of "derivatives, responses, or copies of content generated by the mass-media producers" (Hemsley \&
Mason, 2013, p. 146) that can be re-worked to deceive audiences intentionally or make a political or satirical point (Hemsley \& Snyder, 2018). As such, humorous memes, composite images and mixed media involving the use of irony have come to play an increasingly critical role in digital politics (Tay, 2015) as a way for users to express opinions, build community and mobilize action, as well as a tool for politicians to share policy ideas or to demean their opponents-for instance, during the 2016 Brexit referendum campaign (Dean, 2019; Segesten \& Bossetta, 2017).

Beyond that, connected technological infrastructures have enabled citizens to engage more directly in democratic processes though 'tiny acts' of participation (Margetts et al., 2015). Today, citizens contribute to the public conversation about politics in more ephemeral and intangible ways than before: Broadcasting their support for a cause and seeking to influence others to do the same, through selfies with politicians, and pictures of themselves engaging in various political activities such as rallies and protests (Sorokowska et al., 2016).

Thus, while the literature on the use of visual content in digital communication is growing, it remains in its infancy and offers ample room for elaboration and empirical study. Notably few studies, if any, have explored how specific formats of visuals are mobilized by social media users during electoral campaigns and what political themes they express. Considering this, in this study, we take the 2019 EU Parliamentary elections as a case study to examine the types of images shared over Twitter among two issue publics: Twitter users discussing the elections themselves, and those discussing the more controversial issue of potential withdrawal from the EU.

\section{Methods}

\subsection{Case Selection}

The 2019 European Parliamentary Elections took place between 23-26 May 2019 and witnessed a turnout of $50.66 \%$ of more than 400 million eligible voters to the polls-making it the second largest democratic election in the world (European Parliament, 2019). Across member states, hundreds of candidates and dozens of parties and their supporters campaigned for months over social media, generating vast amounts of campaign material, media coverage and user-generated content. The elections took place against a backdrop of significant divisions in public attitudes towards the EU, with polls underscoring an erosion of trust in European institutions (Guerra \& Serricchio, 2014). The establishment of extreme populist voices within the political mainstream over recent years had stoked experts' fears that Eurosceptic voices would make significant gains in 2019 European Parliamentary Elections. Ahead of the vote, Julian King, then European Commissioner for Security, noted that the dispersed nature and long duration of the European Parliament elections made them 
a "tempting target for malicious actors" (Cerulus, 2019), while Vera Jourova, the then EU Justice Commissioner, warned against "external propagandist pressure" potentially playing out online (Stokel-Walker, 2019). These potential threats around social media interference, combined with the multi-campaigner, multi-issue nature of the mandate thus make the 2019 Parliamentary Elections a pertinent case study.

\subsection{Data Collection and Sampling}

Our data collection proceeded in four stages. We first identified a set of relevant hashtags in English, French, German, Italian, Polish, Spanish, and Swedish intended to capture Twitter traffic around these two separate conversations. While hashtag-based sampling has known limitations, it is a common technique to study 'ad-hoc publics' forming around discussion of specific topics, especially during key political moments (Burgess \& Bruns, 2012; Larsson \& Moe, 2012). The hashtags were compiled by a team of nine research assistants with expert knowledge of these countries' languages and political landscapes (full list of hashtags in the Supplementary File).

Using this set of 84 hashtags, our team then collected a total of 3,620,701 tweets in real time between 13 May and 26 May 2019 through Twitter's Streaming API. This method has knowns limitations: The API only collects $1 \%$ of the global public traffic related to a specific search query at any given time and the company's precise sampling method is unknown (Morstatter, Pfeffer, Liu, \& Carley, 2013), but it remains the only legal way to collect Twitter data without violating terms of services (Freelon, 2018). From this initial dataset we extracted tweets that contained static visuals in their metadata fields. We included tweets if they satisfied one or more of the following criteria: (1) contained at least one of the relevant hashtags; (2) contained the hashtag in a URL shared, or the title of its webpage; (3) were a retweet of a message that contained a relevant hashtag or mention in the original message; or (4) were a quoted tweet referring to a tweet with a relevant hashtag or mention. We then rehydrated each tweet in our set to access the image files, identify tweets that had been removed or deleted since the initial time of posting, resulting in a final dataset of 307,951 tweets with visual content of which 256,204 related to the EU election and 3,164 related to EU exit. To make inferences about both populations, we determine the appropriate sample sizes based on a $95 \%$ confidence interval and a more or less $4 \%$ margin of error, resulting in a random sample of 599 tweets for what we henceforth refer to as the 'General' sample and 505 tweets for the 'Exit' sample. A very small sample of seven images was not accessible.

\subsection{Comparative Content Analysis}

Content analysis is a reliable method for the systemic classification and interpretation of visual representa- tions (Bell, 2004, p. 20; Rose, 2012). We chose this technique over a more interpretive approach in the first instance, in order to allow for a crisp and objective classification and to avoid introducing cultural and personal biases in the analysis of more subtle nuances of messaging and meaning.

We take an inductive approach to codebook development, identifying units of meaning as they emerged from our data before grouping them into larger codes covering two separate aspects of the Twitter images: their format and mode. Here, format describes the type of media shared by users, based on their constitutive elements, while the notion of mode captures the way in which political information is being communicated, based on an image's manifest content and its apparent provenance. Two coders with extensive expertise in content analysis first identified emergent format and modal categories and coded a sub-sample of 100 images drawn from the 'General' and 'Exit' datasets. Any disagreements were discussed among the authors, and initial codes were later adjusted and integrated into broader ones in an iterative process, culminating in seven format and nine modal categories. Intercoder reliability was then determined using Krippendorf's alpha on two independent, non-overlapping sub-samples of 50 images randomly taken from each dataset, achieving high scores.

Visual format ( $\alpha=0.843$ ) includes the following categories: 'Photograph' refers to pictures taken with a camera-including selfies, user-generated, official, and stock photos-that have not been visibly modified. 'Illustration' refers to drawings, sketches, cartoons, and computer-generated images. 'Screen capture' corresponds to images displaying the content of a phone, TV, or computer screen, including captures of webpages, newspaper articles, and screenshots of social media posts. 'Infographic' encompasses visual representations of information and data, including statistics, maps, and visual explainers. A 'Composite' is a visual that has been altered to combine different graphical elements (e.g., photo, text, and drawing), such as photo montages, memes, and GIFs. 'Quote' refers to images featuring a phrase attributed to an individual or plain text that has not been visibly altered. In the 'Poster' category, finally, we include promotional posters, campaign posters, leaflets, event announcements and party logos (Figure 1).

Visual mode ( $\alpha=0.865)$ categories comprise: 'Official campaign communication,' which applies to official campaign material, including political party programs, leaflet and event advertisements, and any communications from official candidate and party accounts. 'Campaign event' applies to images of campaign events, including pictures of rallies, candidate appearances on TV, and photo ops. 'Citizen political engagement' applies to images of private citizens engaging in political activities, such as photographs taken at demonstrations, and individual expressions of support for political causes. 'Political humor' applies to memes, humorous cartoons, 


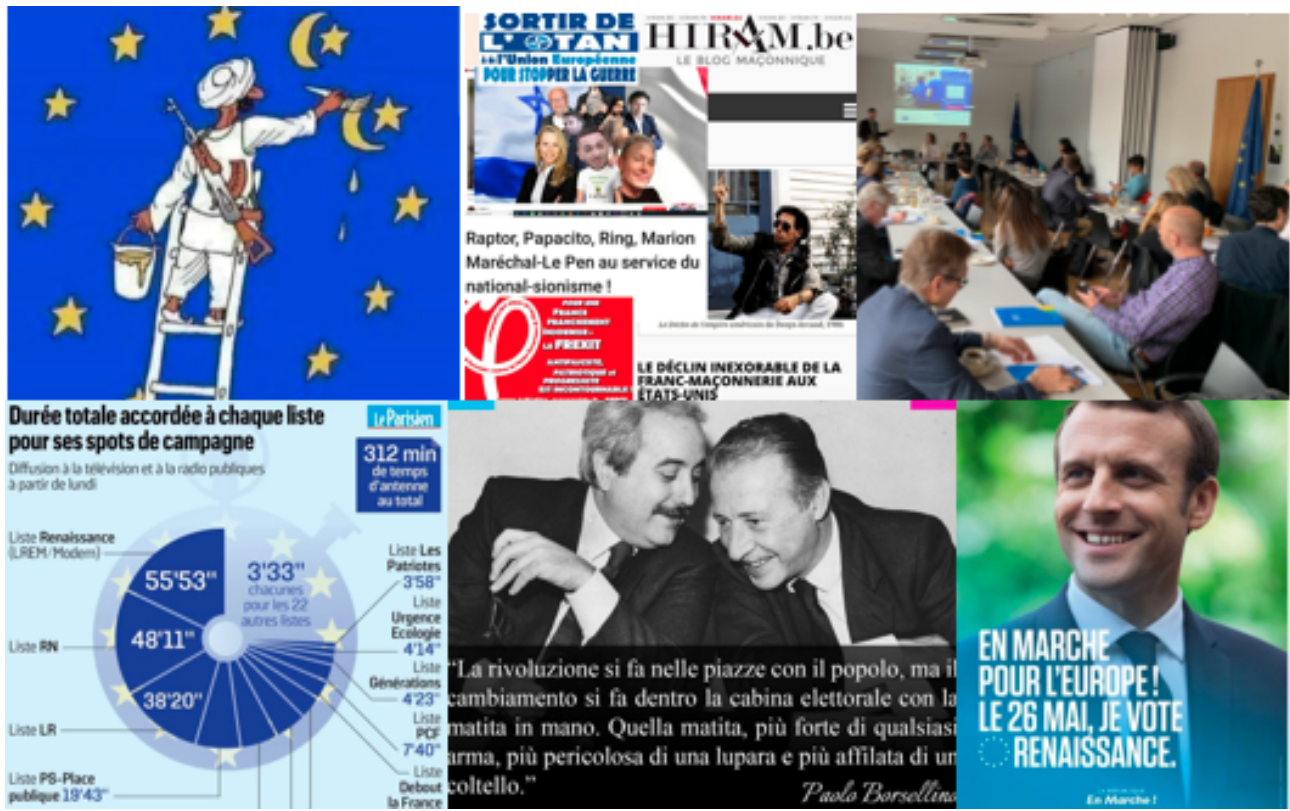

Figure 1. Examples of format categories. Note: From top left to bottom right, examples of an 'illustration,' 'composite,' 'photograph,' 'infographic,' 'quotation' and 'poster.'

satire, and other forms of humor directed at or derived from actors involved in the political process. 'News media reporting' represents images of news media reports, such as newspaper articles, but excludes composites of multiple media sources. 'Non-party and satellite campaigning' applies to campaigning material generated by non-party actors, such as satellite groups (Dommett \& Temple, 2018), registered campaigners, and other "democratic intermediaries" (Edwards, 2006, pp. 8-9). This includes event announcements, unofficial campaign material, and get-out-the-vote initiatives. The category 'Voting day' describes visuals of the vote, such as pictures of ballot cards, and citizens or politicians engaging in the act of voting. 'Other political' applies to other images of political nature that do not specifically relate to the campaign. 'Miscellaneous,' finally, encompasses images unrelated to politics (Figure 2).

\subsection{Thematic Analysis}

Finally, to complement and enrich our systematic content classification, we perform a thematic analysis of visual materials in our samples. Although content and thematic analysis methods share similarities, content analysis lends itself to quantitative summarization of the coded variables, whereas thematic analysis is a more

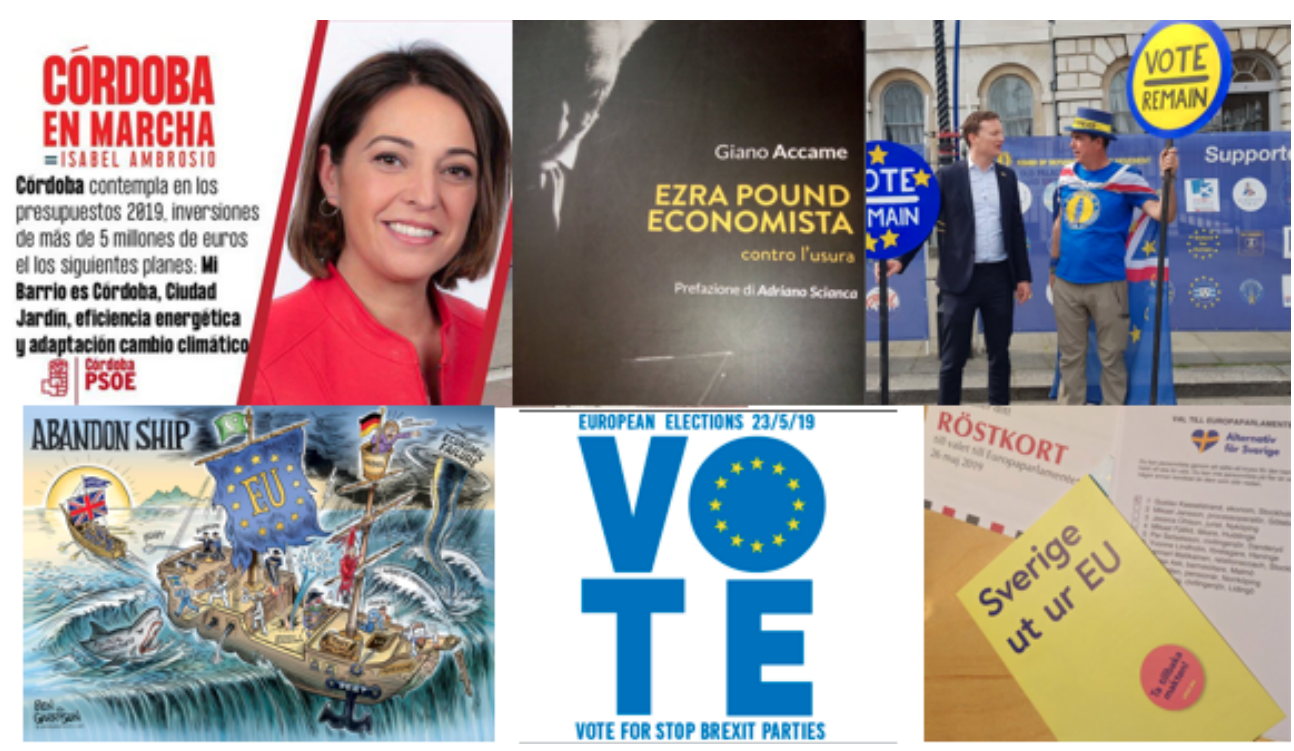

Figure 2. Examples of modal categories. Note: From top left to bottom right, examples of 'official campaign communication,' 'other political,' 'citizen political activism,' 'political humor,' 'satellite campaigning' and 'voting day.' 
interpretive approach that seeks to reveal patterns of meaning in data in context (Neuendorf, 2019). For this task we also followed an inductive process (Clarke, Braun, \& Hayfield, 2015, p. 225), identifying recurrent themes and patterns of meaning as they emerged in the data through semantic and visual symbols without prior theoretical expectations. After familiarizing ourselves with the data, we devised a first round of descriptive codes, which we later grouped to form larger thematic categories based on salience and relevance. One such category pertained to references to policy issues addressed during the election campaign, such as 'economy,' 'security' or 'immigration.' Any references to the elections themselves were grouped under the 'General election' category. Our team treated images of individuals desecrating the European flag, admonishing the European project, or advocating for total disengagement from the EU as conveying a 'Eurosceptic' message, while treating positive references to European integration as 'pro-Europe.' Graphical violence and visual references to extreme ideology were grouped under 'extremism,' while those pushing an anti-elite/establishment rhetoric were assigned to 'populist and anti-elitist.' Up to two codes were assigned to a small fraction of images that touched on more than one theme. While thematic analysis is a qualitatively oriented approach (Braun \& Clarke, 2006) we include frequency counts for each category to understand what topics different forms of political expressions touched on.

\section{Findings}

\subsection{Format}

Table 1 shows that photographs are by far the most prevalent format across both 'General' and 'Exit' samples, making up $38.7 \%$ and $23.8 \%$ of all images, respectively. Posters were shared slightly more frequently in the 'General' conversation, where they comprised $21.9 \%$ of all images compared to $20.4 \%$ for 'Exit.' Proportions of illustrations (6.2\% in 'General,' $8 \%$ in 'Exit') and screen captures (12.9\% in 'General,' $9 \%$ in 'Exit') were commensurate across both samples. Both datasets display stark differences when it comes to composites, however, with tweets focusing on EU withdrawal containing more than twice $(22.4 \%)$ the number of composites than 'General' tweets (9.9\%). Quotes and text only accounted for a fraction of all images in the 'General' dataset (2.7\%) compared to the 'Exit' one (12.2\%).

\subsection{Mode}

Table 1 reveals that official campaign material was the most shared mode in both 'General' and 'Exit'-related conversations, comprising $18.8 \%$ and $26.1 \%$ of images respectively. In the 'General' dataset, polls (10.6\%), political humor $(10.1 \%)$, images of voting day $(10.1 \%)$ and unofficial campaign material (9.9\%) made up almost equal proportions of content, while other political

Table 1. Frequency of visual formats and modes across both samples.

\begin{tabular}{|c|c|c|c|c|}
\hline & \multicolumn{2}{|c|}{ 'General' Sample } & \multicolumn{2}{|c|}{ 'Exit' Sample } \\
\hline & $\mathrm{N}$ & $\%$ & $\mathrm{~N}$ & $\%$ \\
\hline \multicolumn{5}{|l|}{ Format Code } \\
\hline Photograph & 231 & 38.7 & 119 & 23.8 \\
\hline Illustration & 37 & 6.2 & 40 & 8.0 \\
\hline Screen captures & 77 & 12.9 & 45 & 9.0 \\
\hline Infographic & 45 & 7.6 & 22 & 4.4 \\
\hline Composite & 59 & 9.9 & 112 & 22.4 \\
\hline Quotes \& Text & 16 & 2.7 & 61 & 12.2 \\
\hline Poster & 131 & 21.9 & 102 & 20.4 \\
\hline Total & 596 & 100.0 & 501 & 100.0 \\
\hline \multicolumn{5}{|l|}{ Modal Code } \\
\hline Official Campaign Material & 112 & 18.8 & 131 & 26.1 \\
\hline Voting Day & 60 & 10.1 & 24 & 4.8 \\
\hline Campaign Event & 82 & 13.8 & 40 & 8.0 \\
\hline Citizen Political Activism & 40 & 6.7 & 15 & 3.0 \\
\hline Polls & 63 & 10.6 & 7 & 1.4 \\
\hline Political Humor & 60 & 10.1 & 98 & 19.6 \\
\hline Satellite Campaign Material & 59 & 9.9 & 60 & 12.0 \\
\hline Other Political & 50 & 8.4 & 80 & 16.0 \\
\hline News Reporting & 26 & 4.4 & 32 & 6.4 \\
\hline Miscellaneous/Spam & 44 & 7.4 & 14 & 2.8 \\
\hline Total & 596 & 100.0 & 501 & 100.0 \\
\hline
\end{tabular}


images (8.4\%), depictions of citizens engaging in political activity (6.7\%) and news reports (4.4\%) accounted for smaller proportions. Interestingly, politically humorous images were twice as present in 'Exit'-related tweets (19.6\%), making them the second most popular mode of visual communication in this dataset, closely followed by other political images (16\%). Here again, satellite and unofficial campaign material accounted for a substantial number of images with $12 \%$ of shares. Polls, finally, were mostly irrelevant to discussions around 'Exit' from the EU featuring in only $1.4 \%$ of tweets compared to $10.6 \%$ in the 'General' sample.

\subsection{Themes}

Table 2 displays the most salient themes in each sample. Comparing both datasets reveals some important differences. Most visual tweets in the 'General' dataset made reference to the 2019 EU Parliamentary Elections themselves (19\%) or to multiple policy issues (10.6\%). It is noteworthy, however, that the great majority of images shared were not attributed a thematic category. The salience of a policy issue in political discourse is a powerful indicator of its importance to the public. Yet, only a small proportion of visuals captured in our data made references to specific policies, such as security or immigration (less than $2 \%$ in both samples). In the 'Exit' sample, $41.9 \%$ of images propagated a Eurosceptic and anti-European message, making it the largest thematic category. In the 'General' sample, only $3.5 \%$ of images were classified as Eurosceptic, with double the share of images sharing pro-EU themes (6.7\%). Finally, 9.4\% of images shared in discussions of potential 'Exit' from the EU conveyed populist and anti-establishment sentiment, mainly consisting of derogatory or hateful messages visà-vis political elites.

\subsection{Cross-Category Dependencies}

Having identified the most salient content categories in each dataset, as a final step we investigate the relation- ships between format and modal categories on the one hand, and between modal and thematic categories on the other hand. Tables 3 and 4 reveal several interesting similarities and differences between samples. Across both 'General' and 'Exit' samples, photographs were mostly shared to depict campaign events, including party rallies ( $30 \%$ of photographs), with substantial proportions also alluding to voting day (24\% in 'General,' $20 \%$ in 'Exit'). In 'Exit'-related tweets, photographs formed a core part of official campaign communication $120 \%$ of images in this mode, compared to $7 \%$ in the 'General' sample), where they often portrayed party volunteers canvassing. Illustrations, cartoons and drawings were the most common vehicle for political humor-the single largest category across samples for this format (62\% in 'General,' 48\% in 'Exit')-closely followed by composites and user-generated memes (42\% in 'General,' 60\% in 'Exit'). Across both samples, posters overwhelmingly corresponded to official campaign material, with 63\% of posters in the 'General' and $85 \%$ of those in the 'Exit' sample taking the form of paper or digital campaign posters.

The relationships between modal and thematic categories are shown in Tables 5 and 6 . In the conversation pertaining to the election at large, visual messages predictably revolved around the conduct of the election itself, often in the form of opinion and election polls (95\% of images in this mode), as well as news reports (54\%). Many also pushed a distinctly 'pro-EU' line, mostly through satellite campaign material from pro-EU groups and citizen-led initiatives to 'get-out-thevote' for Europe (24\%). Tweets shared with EU exit hashtags, on the other hand, overwhelmingly pushed Eurosceptic and populist/anti-establishment messages. Interestingly, these were mostly conveyed through satellite and unofficial campaigning material ( $87 \%$ of which carried a distinctly anti-EU message) and through political humor, where $50 \%$ and $33 \%$ of all images in this visual mode assumed either Eurosceptic or anti-elitist tones. In contrast to the 'General' dataset, polls shared in 'Exit'-related tweets were mostly shared to convey public

Table 2. Frequency of thematic categories across both samples.

\begin{tabular}{lrrrr}
\hline & \multicolumn{2}{c}{ 'General' Sample } & \multicolumn{2}{c}{ 'Exit' Sample } \\
\hline Salient Theme & \multicolumn{1}{c}{$\mathrm{N}$} & $\%$ & $\mathrm{~N}$ & \multicolumn{1}{c}{$\%$} \\
\hline Security/Terrorism & 3 & 0.5 & 210 & 1.4 \\
Euroscepticism & 21 & 3.5 & 0 & 41.9 \\
Pro-EU & 40 & 6.7 & 18 & 0.0 \\
General Election & 113 & 19.0 & 21 & 3.6 \\
Extremism & 7 & 1.2 & 47 & 4.2 \\
Populist Anti-Elitism & 11 & 1.8 & 5 & 9.4 \\
Economy & 8 & 1.3 & 11 & 1.0 \\
Immigration & 8 & 1.3 & 6 & 2.2 \\
Multi-Issue & 63 & 10.6 & 176 & 1.2 \\
No Salient Theme & 322 & 54.1 & 501 & 35.1 \\
Total & 596 & 100.0 & 100.0 \\
\hline
\end{tabular}


Table 3. Cross tabulations of visual and modal categories in 'General' sample (N, \%).

\begin{tabular}{|c|c|c|c|c|c|c|c|c|c|c|c|}
\hline & $\begin{array}{c}\text { Official } \\
\text { Campaign }\end{array}$ & $\begin{array}{l}\text { Voting } \\
\text { Day }\end{array}$ & $\begin{array}{c}\text { Campaign } \\
\text { Event }\end{array}$ & $\begin{array}{c}\text { Citizen } \\
\text { Activism }\end{array}$ & Polls & $\begin{array}{c}\text { Political } \\
\text { Humor }\end{array}$ & $\begin{array}{c}\text { Satellite } \\
\text { Campaign }\end{array}$ & $\begin{array}{c}\text { Other } \\
\text { Political }\end{array}$ & $\begin{array}{c}\text { News } \\
\text { Reporting }\end{array}$ & $\begin{array}{c}\text { Misc. \& } \\
\text { Spam }\end{array}$ & Total \\
\hline Photograph & $\begin{array}{c}16 \\
(7 \%)\end{array}$ & $\begin{array}{c}56 \\
(24 \%)\end{array}$ & $\begin{array}{c}69 \\
(30 \%)\end{array}$ & $\begin{array}{c}26 \\
(11 \%)\end{array}$ & $\begin{array}{c}4 \\
(2 \%)\end{array}$ & $\begin{array}{c}6 \\
(3 \%)\end{array}$ & $\begin{array}{c}0 \\
(0 \%)\end{array}$ & $\begin{array}{c}17 \\
(7 \%)\end{array}$ & $\begin{array}{c}3 \\
(1 \%)\end{array}$ & $\begin{array}{c}34 \\
(15 \%)\end{array}$ & 231 \\
\hline Illustrations & $\begin{array}{c}1 \\
(3 \%)\end{array}$ & $\begin{array}{c}1 \\
(3 \%)\end{array}$ & $\begin{array}{c}0 \\
(0 \%)\end{array}$ & $\begin{array}{c}0 \\
(0 \%)\end{array}$ & $\begin{array}{c}0 \\
(0 \%)\end{array}$ & $\begin{array}{c}23 \\
(62 \%)\end{array}$ & $\begin{array}{c}2 \\
(5 \%)\end{array}$ & $\begin{array}{c}8 \\
(22 \%)\end{array}$ & $\begin{array}{c}0 \\
(0 \%)\end{array}$ & $\begin{array}{c}2 \\
(5 \%)\end{array}$ & 37 \\
\hline Screenshots & $\begin{array}{c}7 \\
(9 \%)\end{array}$ & $\begin{array}{c}0 \\
(0 \%)\end{array}$ & $\begin{array}{c}8 \\
(10 \%)\end{array}$ & $\begin{array}{c}8 \\
(10 \%)\end{array}$ & $\begin{array}{c}20 \\
(26 \%)\end{array}$ & $\begin{array}{c}1 \\
(1 \%)\end{array}$ & $\begin{array}{c}4 \\
(5 \%)\end{array}$ & $\begin{array}{c}4 \\
(5 \%)\end{array}$ & $\begin{array}{c}20 \\
(26 \%)\end{array}$ & $\begin{array}{c}5 \\
(6 \%)\end{array}$ & 77 \\
\hline Infographic & $\begin{array}{c}0 \\
(0 \%)\end{array}$ & $\begin{array}{c}0 \\
(0 \%)\end{array}$ & $\begin{array}{c}0 \\
(0 \%)\end{array}$ & $\begin{array}{c}0 \\
(0 \%)\end{array}$ & $\begin{array}{c}39 \\
(87 \%)\end{array}$ & $\begin{array}{c}0 \\
(0 \%)\end{array}$ & $\begin{array}{c}1 \\
(2 \%)\end{array}$ & $\begin{array}{c}2 \\
(4 \%)\end{array}$ & $\begin{array}{c}1 \\
(2 \%)\end{array}$ & $\begin{array}{c}2 \\
(4 \%)\end{array}$ & 45 \\
\hline Composite & $\begin{array}{c}3 \\
(5 \%)\end{array}$ & $\begin{array}{c}3 \\
(5 \%)\end{array}$ & $\begin{array}{c}4 \\
(7 \%)\end{array}$ & $\begin{array}{c}3 \\
(5 \%)\end{array}$ & $\begin{array}{c}0 \\
(0 \%)\end{array}$ & $\begin{array}{c}25 \\
(42 \%)\end{array}$ & $\begin{array}{c}15 \\
(25 \%)\end{array}$ & $\begin{array}{c}5 \\
(8 \%)\end{array}$ & $\begin{array}{c}1 \\
(2 \%)\end{array}$ & $\begin{array}{c}0 \\
(0 \%)\end{array}$ & 59 \\
\hline Quotes & $\begin{array}{c}2 \\
(13 \%)\end{array}$ & $\begin{array}{c}0 \\
(0 \%)\end{array}$ & $\begin{array}{c}0 \\
(0 \%)\end{array}$ & $\begin{array}{c}1 \\
(6 \%)\end{array}$ & $\begin{array}{c}0 \\
(0 \%)\end{array}$ & $\begin{array}{c}1 \\
(6 \%)\end{array}$ & $\begin{array}{c}6 \\
(38 \%)\end{array}$ & $\begin{array}{c}6 \\
(38 \%)\end{array}$ & $\begin{array}{c}0 \\
(0 \%)\end{array}$ & $\begin{array}{c}0 \\
(0 \%)\end{array}$ & 16 \\
\hline Poster & $\begin{array}{c}83 \\
(63 \%)\end{array}$ & $\begin{array}{c}0 \\
(0 \%)\end{array}$ & $\begin{array}{c}1 \\
(1 \%)\end{array}$ & $\begin{array}{c}2 \\
(2 \%)\end{array}$ & $\begin{array}{c}0 \\
(0 \%)\end{array}$ & $\begin{array}{c}4 \\
(3 \%)\end{array}$ & $\begin{array}{c}31 \\
(24 \%)\end{array}$ & $\begin{array}{c}8 \\
(6 \%)\end{array}$ & $\begin{array}{c}1 \\
(1 \%)\end{array}$ & $\begin{array}{c}1 \\
(1 \%)\end{array}$ & 131 \\
\hline Total & 112 & 60 & 82 & 40 & 63 & 60 & 59 & 50 & 26 & 44 & \\
\hline
\end{tabular}

attitudes around membership in the EU or referred to various 2005 EU Constitution referenda. While depictions of citizen political activism were either pro-Europe or spoke to multiple policy issues in the 'General' sample ( $20 \%$ of images in each mode), in the 'Exit' sample they were almost exclusively mobilized to convey Eurosceptic visual symbols (87\%).

\section{Discussion}

This research set out to identify and quantify the formats and modes of visual political communication mobilized by Twitter users in the lead up to 2019 European Parliamentary elections, and to determine if and how these varied in relation to contentiousness of discourse. Furthermore, our analysis sought to uncover the underlying themes conveyed through visuals. To this end, we developed a rigorous, multi-step scheme for categorizing visual content based on a multilingual, crosscase analysis of real-time Twitter data covering six European language spheres-English, French, German, Italian, Spanish and Swedish. Our findings underscore that visual media played a central role in the Twitter political discourse ahead of the 2019 European Parliamentary Elections, both as a conduit for official campaigning and candidate communications and for novel forms of political expression and user-generated political content. Three trends stand out from our analysis.

Table 4. Cross tabulations of visual and modal categories in 'Exit' sample (N, \%).

\begin{tabular}{|c|c|c|c|c|c|c|c|c|c|c|c|}
\hline & $\begin{array}{c}\text { Official } \\
\text { Campaign }\end{array}$ & $\begin{array}{l}\text { Voting } \\
\text { Day }\end{array}$ & $\begin{array}{c}\text { Campaign } \\
\text { Event }\end{array}$ & $\begin{array}{c}\text { Citizen } \\
\text { Activism }\end{array}$ & Polls & $\begin{array}{c}\text { Political } \\
\text { Humor }\end{array}$ & $\begin{array}{c}\text { Satellite } \\
\text { Campaign }\end{array}$ & $\begin{array}{c}\text { Other } \\
\text { Political }\end{array}$ & $\begin{array}{c}\text { News } \\
\text { Reporting }\end{array}$ & $\begin{array}{c}\text { Misc. \& } \\
\text { Spam }\end{array}$ & Total \\
\hline Photograph & $\begin{array}{c}24 \\
(20 \%)\end{array}$ & $\begin{array}{c}24 \\
(20 \%)\end{array}$ & $\begin{array}{c}36 \\
(30 \%)\end{array}$ & $\begin{array}{c}9 \\
(8 \%)\end{array}$ & $\begin{array}{c}0 \\
(0 \%)\end{array}$ & $\begin{array}{c}0 \\
(0 \%)\end{array}$ & $\begin{array}{c}1 \\
(1 \%)\end{array}$ & $\begin{array}{c}16 \\
(13 \%)\end{array}$ & $\begin{array}{c}1 \\
(1 \%)\end{array}$ & $\begin{array}{c}8 \\
(7 \%)\end{array}$ & 119 \\
\hline Illustrations & $\begin{array}{c}1 \\
(3 \%)\end{array}$ & $\begin{array}{c}0 \\
(0 \%)\end{array}$ & $\begin{array}{c}0 \\
(0 \%)\end{array}$ & $\begin{array}{c}0 \\
(0 \%)\end{array}$ & $\begin{array}{c}0 \\
(0 \%)\end{array}$ & $\begin{array}{c}19 \\
(48 \%)\end{array}$ & $\begin{array}{c}9 \\
(23 \%)\end{array}$ & $\begin{array}{c}8 \\
(20 \%)\end{array}$ & $\begin{array}{c}1 \\
(3 \%)\end{array}$ & $\begin{array}{c}2 \\
(5 \%)\end{array}$ & 40 \\
\hline Screenshots & $\begin{array}{c}3 \\
(7 \%)\end{array}$ & $\begin{array}{c}0 \\
(0 \%)\end{array}$ & $\begin{array}{c}3 \\
(7 \%)\end{array}$ & $\begin{array}{c}3 \\
(7 \%)\end{array}$ & $\begin{array}{c}1 \\
(2 \%)\end{array}$ & $\begin{array}{c}0 \\
(0 \%)\end{array}$ & $\begin{array}{c}1 \\
(2 \%)\end{array}$ & $\begin{array}{c}6 \\
(13 \%)\end{array}$ & $\begin{array}{c}27 \\
(60 \%)\end{array}$ & $\begin{array}{c}1 \\
(2 \%)\end{array}$ & 45 \\
\hline Infographic & $\begin{array}{c}0 \\
(0 \%)\end{array}$ & $\begin{array}{c}0 \\
(0 \%)\end{array}$ & $\begin{array}{c}1 \\
(5 \%)\end{array}$ & $\begin{array}{c}0 \\
(0 \%)\end{array}$ & $\begin{array}{c}5 \\
(23 \%)\end{array}$ & $\begin{array}{c}11 \\
(50 \%)\end{array}$ & $\begin{array}{c}2 \\
(9 \%)\end{array}$ & $\begin{array}{c}2 \\
(9 \%)\end{array}$ & $\begin{array}{c}1 \\
(5 \%)\end{array}$ & $\begin{array}{c}0 \\
(0 \%)\end{array}$ & 22 \\
\hline Composite & $\begin{array}{c}2 \\
(2 \%)\end{array}$ & $\begin{array}{c}0 \\
(0 \%)\end{array}$ & $\begin{array}{c}0 \\
(0 \%)\end{array}$ & $\begin{array}{c}0 \\
(0 \%)\end{array}$ & $\begin{array}{c}1 \\
(1 \%)\end{array}$ & $\begin{array}{c}67 \\
(60 \%)\end{array}$ & $\begin{array}{c}30 \\
(27 \%)\end{array}$ & $\begin{array}{c}11 \\
(10 \%)\end{array}$ & $\begin{array}{c}0 \\
(0 \%)\end{array}$ & $\begin{array}{c}1 \\
(1 \%)\end{array}$ & 112 \\
\hline Quotes & $\begin{array}{c}14 \\
(23 \%)\end{array}$ & $\begin{array}{c}0 \\
(0 \%)\end{array}$ & $\begin{array}{c}0 \\
(0 \%)\end{array}$ & $\begin{array}{c}3 \\
(5 \%)\end{array}$ & $\begin{array}{c}0 \\
(0 \%)\end{array}$ & $\begin{array}{c}1 \\
(2 \%)\end{array}$ & $\begin{array}{c}5 \\
(8 \%)\end{array}$ & $\begin{array}{c}35 \\
(57 \%)\end{array}$ & $\begin{array}{c}2 \\
(3 \%)\end{array}$ & $\begin{array}{c}1 \\
(2 \%)\end{array}$ & 61 \\
\hline Poster & $\begin{array}{c}87 \\
(85 \%)\end{array}$ & $\begin{array}{c}0 \\
(0 \%)\end{array}$ & $\begin{array}{c}0 \\
(0 \%)\end{array}$ & $\begin{array}{c}0 \\
(0 \%)\end{array}$ & $\begin{array}{c}0 \\
(0 \%)\end{array}$ & $\begin{array}{c}0 \\
(0 \%)\end{array}$ & $\begin{array}{c}12 \\
(12 \%)\end{array}$ & $\begin{array}{c}2 \\
(2 \%)\end{array}$ & $\begin{array}{c}0 \\
(0 \%)\end{array}$ & $\begin{array}{c}1 \\
(1 \%)\end{array}$ & 102 \\
\hline Total & 131 & 24 & 40 & 15 & 7 & 98 & 60 & 80 & 32 & 14 & \\
\hline
\end{tabular}


Table 5. Cross tabulations of visuals modes and themes in 'General' sample.

\begin{tabular}{|c|c|c|c|c|c|c|c|c|c|}
\hline & $\begin{array}{l}\text { Pro- } \\
\text { Europe }\end{array}$ & Eurosceptic & $\begin{array}{c}\text { Populist } \\
\text { Anti-Elitism }\end{array}$ & Extremism & $\begin{array}{l}\text { General } \\
\text { Election }\end{array}$ & Economy & $\begin{array}{l}\text { Multi- } \\
\text { Issue }\end{array}$ & $\begin{array}{l}\text { Security/ } \\
\text { Terrorism }\end{array}$ & Immigration \\
\hline $\begin{array}{l}\text { Official } \\
\text { Campaigning }\end{array}$ & $\begin{array}{c}4 \\
(4 \%)\end{array}$ & $\begin{array}{c}13 \\
(12 \%)\end{array}$ & $\begin{array}{c}0 \\
(0 \%)\end{array}$ & $\begin{array}{c}1 \\
(1 \%)\end{array}$ & $\begin{array}{c}0 \\
(0 \%)\end{array}$ & $\begin{array}{c}4 \\
(4 \%)\end{array}$ & $\begin{array}{c}24 \\
(21 \%)\end{array}$ & $\begin{array}{c}0 \\
(0 \%)\end{array}$ & $\begin{array}{c}4 \\
(4 \%)\end{array}$ \\
\hline Voting Day & $\begin{array}{c}1 \\
(2 \%)\end{array}$ & $\begin{array}{c}0 \\
(0 \%)\end{array}$ & $\begin{array}{c}0 \\
(0 \%)\end{array}$ & $\begin{array}{c}0 \\
(0 \%)\end{array}$ & $\begin{array}{c}0 \\
(0 \%)\end{array}$ & $\begin{array}{c}0 \\
(0 \%)\end{array}$ & $\begin{array}{c}0 \\
(0 \%)\end{array}$ & $\begin{array}{c}0 \\
(0 \%)\end{array}$ & $\begin{array}{c}0 \\
(0 \%)\end{array}$ \\
\hline $\begin{array}{l}\text { Campaign } \\
\text { Event }\end{array}$ & $\begin{array}{c}3 \\
(4 \%)\end{array}$ & $\begin{array}{c}0 \\
(0 \%)\end{array}$ & $\begin{array}{c}0 \\
(0 \%)\end{array}$ & $\begin{array}{c}0 \\
(0 \%)\end{array}$ & $\begin{array}{c}3 \\
(4 \%)\end{array}$ & $\begin{array}{c}0 \\
(0 \%)\end{array}$ & $\begin{array}{c}1 \\
(1 \%)\end{array}$ & $\begin{array}{c}0 \\
(0 \%)\end{array}$ & $\begin{array}{c}0 \\
(0 \%)\end{array}$ \\
\hline $\begin{array}{l}\text { Citizen } \\
\text { Activism }\end{array}$ & $\begin{array}{c}8 \\
(20 \%)\end{array}$ & $\begin{array}{c}1 \\
(3 \%)\end{array}$ & $\begin{array}{c}1 \\
(3 \%)\end{array}$ & $\begin{array}{c}2 \\
(5 \%)\end{array}$ & $\begin{array}{c}0 \\
(0 \%)\end{array}$ & $\begin{array}{c}1 \\
(3 \%)\end{array}$ & $\begin{array}{c}8 \\
(20 \%)\end{array}$ & $\begin{array}{c}1 \\
(3 \%)\end{array}$ & $\begin{array}{c}0 \\
(0 \%)\end{array}$ \\
\hline Polls & $\begin{array}{c}0 \\
(0 \%)\end{array}$ & $\begin{array}{c}1 \\
(2 \%)\end{array}$ & $\begin{array}{c}0 \\
(0 \%)\end{array}$ & $\begin{array}{c}0 \\
(0 \%)\end{array}$ & $\begin{array}{c}60 \\
(95 \%)\end{array}$ & $\begin{array}{c}0 \\
(0 \%)\end{array}$ & $\begin{array}{c}0 \\
(0 \%)\end{array}$ & $\begin{array}{c}0 \\
(0 \%)\end{array}$ & $\begin{array}{c}0 \\
(0 \%)\end{array}$ \\
\hline $\begin{array}{l}\text { Political } \\
\text { Humor }\end{array}$ & $\begin{array}{c}8 \\
(13 \%)\end{array}$ & $\begin{array}{c}5 \\
(8 \%)\end{array}$ & $\begin{array}{c}3 \\
(5 \%)\end{array}$ & $\begin{array}{c}2 \\
(3 \%)\end{array}$ & $\begin{array}{c}10 \\
(17 \%)\end{array}$ & $\begin{array}{c}1 \\
(2 \%)\end{array}$ & $\begin{array}{c}10 \\
(17 \%)\end{array}$ & $\begin{array}{c}2 \\
(3 \%)\end{array}$ & $\begin{array}{c}1 \\
(2 \%)\end{array}$ \\
\hline $\begin{array}{l}\text { Satellite } \\
\text { Campaigning }\end{array}$ & $\begin{array}{c}14 \\
(24 \%)\end{array}$ & $\begin{array}{c}1 \\
(2 \%)\end{array}$ & $\begin{array}{c}2 \\
(3 \%)\end{array}$ & $\begin{array}{c}1 \\
(2 \%)\end{array}$ & $\begin{array}{c}0 \\
(0 \%)\end{array}$ & $\begin{array}{c}1 \\
(2 \%)\end{array}$ & $\begin{array}{c}11 \\
(19 \%)\end{array}$ & $\begin{array}{c}0 \\
(0 \%)\end{array}$ & $\begin{array}{c}2 \\
(3 \%)\end{array}$ \\
\hline $\begin{array}{l}\text { Other } \\
\text { Political }\end{array}$ & $\begin{array}{c}2 \\
(4 \%)\end{array}$ & $\begin{array}{c}0 \\
(0 \%)\end{array}$ & $\begin{array}{c}3 \\
(6 \%)\end{array}$ & $\begin{array}{c}0 \\
(0 \%)\end{array}$ & $\begin{array}{c}0 \\
(0 \%)\end{array}$ & $\begin{array}{c}0 \\
(0 \%)\end{array}$ & $\begin{array}{c}3 \\
(6 \%)\end{array}$ & $\begin{array}{c}0 \\
(0 \%)\end{array}$ & $\begin{array}{c}0 \\
(0 \%)\end{array}$ \\
\hline Reporting & $\begin{array}{c}0 \\
(0 \%)\end{array}$ & $\begin{array}{c}0 \\
(0 \%)\end{array}$ & $\begin{array}{c}2 \\
(8 \%)\end{array}$ & $\begin{array}{c}1 \\
(4 \%)\end{array}$ & $\begin{array}{c}14 \\
(54 \%)\end{array}$ & $\begin{array}{c}1 \\
(4 \%)\end{array}$ & $\begin{array}{c}6 \\
(23 \%)\end{array}$ & $\begin{array}{c}0 \\
(0 \%)\end{array}$ & $\begin{array}{c}1 \\
(4 \%)\end{array}$ \\
\hline Misc./Spam & $\begin{array}{c}0 \\
(0 \%)\end{array}$ & $\begin{array}{c}0 \\
(0 \%)\end{array}$ & $\begin{array}{c}0 \\
(0 \%)\end{array}$ & $\begin{array}{c}0 \\
(0 \%)\end{array}$ & $\begin{array}{c}0 \\
(0 \%)\end{array}$ & $\begin{array}{c}0 \\
(0 \%)\end{array}$ & $\begin{array}{c}0 \\
(0 \%)\end{array}$ & $\begin{array}{c}0 \\
(0 \%)\end{array}$ & $\begin{array}{c}0 \\
(0 \%)\end{array}$ \\
\hline
\end{tabular}

Note: Number of images in each sample, followed by percentages of all images in the relevant mode.

Table 6. Cross tabulations of visuals modes and themes in 'Exit' sample.

\begin{tabular}{|c|c|c|c|c|c|c|c|c|c|}
\hline & $\begin{array}{c}\text { Pro- } \\
\text { Europe }\end{array}$ & Eurosceptic & $\begin{array}{c}\text { Populist } \\
\text { Anti-Elitism }\end{array}$ & Extremism & $\begin{array}{l}\text { General } \\
\text { Election }\end{array}$ & Economy & $\begin{array}{l}\text { Multi- } \\
\text { Issue }\end{array}$ & $\begin{array}{l}\text { Security/ } \\
\text { Terrorism }\end{array}$ & Immigration \\
\hline $\begin{array}{l}\text { Official } \\
\text { Campaigning }\end{array}$ & $\begin{array}{c}0 \\
(0 \%)\end{array}$ & $\begin{array}{c}42 \\
(32 \%)\end{array}$ & $\begin{array}{c}0 \\
(0 \%)\end{array}$ & $\begin{array}{c}0 \\
(0 \%)\end{array}$ & $\begin{array}{c}0 \\
(0 \%)\end{array}$ & $\begin{array}{c}0 \\
(0 \%)\end{array}$ & $\begin{array}{c}0 \\
(0 \%)\end{array}$ & $\begin{array}{c}0 \\
(0 \%)\end{array}$ & $\begin{array}{c}0 \\
(0 \%)\end{array}$ \\
\hline Voting Day & $\begin{array}{c}0 \\
(0 \%)\end{array}$ & $\begin{array}{c}11 \\
(46 \%)\end{array}$ & $\begin{array}{c}0 \\
(0 \%)\end{array}$ & $\begin{array}{c}0 \\
(0 \%)\end{array}$ & $\begin{array}{c}0 \\
(0 \%)\end{array}$ & $\begin{array}{c}0 \\
(0 \%)\end{array}$ & $\begin{array}{c}0 \\
(0 \%)\end{array}$ & $\begin{array}{c}0 \\
(0 \%)\end{array}$ & $\begin{array}{c}0 \\
(0 \%)\end{array}$ \\
\hline $\begin{array}{l}\text { Campaign } \\
\text { Event }\end{array}$ & $\begin{array}{c}0 \\
(0 \%)\end{array}$ & $\begin{array}{c}12 \\
(30 \%)\end{array}$ & $\begin{array}{c}0 \\
(0 \%)\end{array}$ & $\begin{array}{c}0 \\
(0 \%)\end{array}$ & $\begin{array}{c}0 \\
(0 \%)\end{array}$ & $\begin{array}{c}0 \\
(0 \%)\end{array}$ & $\begin{array}{c}0 \\
(0 \%)\end{array}$ & $\begin{array}{c}0 \\
(0 \%)\end{array}$ & $\begin{array}{c}0 \\
(0 \%)\end{array}$ \\
\hline $\begin{array}{l}\text { Citizen Political } \\
\text { Activism }\end{array}$ & $\begin{array}{c}0 \\
(0 \%)\end{array}$ & $\begin{array}{c}13 \\
(87 \%)\end{array}$ & $\begin{array}{c}2 \\
(13 \%)\end{array}$ & $\begin{array}{c}1 \\
(7 \%)\end{array}$ & $\begin{array}{c}0 \\
(0 \%)\end{array}$ & $\begin{array}{c}0 \\
(0 \%)\end{array}$ & $\begin{array}{c}1 \\
(7 \%)\end{array}$ & $\begin{array}{c}0 \\
(0 \%)\end{array}$ & $\begin{array}{c}0 \\
(0 \%)\end{array}$ \\
\hline Polls & $\begin{array}{c}0 \\
(0 \%)\end{array}$ & $\begin{array}{c}6 \\
(86 \%)\end{array}$ & $\begin{array}{c}0 \\
(0 \%)\end{array}$ & $\begin{array}{c}0 \\
(0 \%)\end{array}$ & $\begin{array}{c}1 \\
(14 \%)\end{array}$ & $\begin{array}{c}0 \\
(0 \%)\end{array}$ & $\begin{array}{c}0 \\
(0 \%)\end{array}$ & $\begin{array}{c}0 \\
(0 \%)\end{array}$ & $\begin{array}{c}0 \\
(0 \%)\end{array}$ \\
\hline $\begin{array}{l}\text { Political } \\
\text { Humor }\end{array}$ & $\begin{array}{c}0 \\
(0 \%)\end{array}$ & $\begin{array}{c}50 \\
(51 \%)\end{array}$ & $\begin{array}{c}32 \\
(33 \%)\end{array}$ & $\begin{array}{c}14 \\
(14 \%)\end{array}$ & $\begin{array}{c}0 \\
(0 \%)\end{array}$ & $\begin{array}{c}1 \\
(1 \%)\end{array}$ & $\begin{array}{c}0 \\
(0 \%)\end{array}$ & $\begin{array}{c}0 \\
(0 \%)\end{array}$ & $\begin{array}{c}1 \\
(1 \%)\end{array}$ \\
\hline $\begin{array}{l}\text { Satellite } \\
\text { Campaigning }\end{array}$ & $\begin{array}{c}0 \\
(0 \%)\end{array}$ & $\begin{array}{c}52 \\
(87 \%)\end{array}$ & $\begin{array}{c}5 \\
(8 \%)\end{array}$ & $\begin{array}{c}3 \\
(5 \%)\end{array}$ & $\begin{array}{c}0 \\
(0 \%)\end{array}$ & $\begin{array}{c}0 \\
(0 \%)\end{array}$ & $\begin{array}{c}1 \\
(2 \%)\end{array}$ & $\begin{array}{c}0 \\
(0 \%)\end{array}$ & $\begin{array}{c}1 \\
(2 \%)\end{array}$ \\
\hline $\begin{array}{l}\text { Other } \\
\text { Political }\end{array}$ & $\begin{array}{c}0 \\
(0 \%)\end{array}$ & $\begin{array}{c}22 \\
(28 \%)\end{array}$ & $\begin{array}{c}7 \\
(9 \%)\end{array}$ & $\begin{array}{c}3 \\
(4 \%)\end{array}$ & $\begin{array}{c}1 \\
(1 \%)\end{array}$ & $\begin{array}{c}1 \\
(1 \%)\end{array}$ & $\begin{array}{c}2 \\
(3 \%)\end{array}$ & $\begin{array}{c}7 \\
(9 \%)\end{array}$ & $\begin{array}{c}0 \\
(0 \%)\end{array}$ \\
\hline Reporting & $\begin{array}{c}0 \\
(0 \%)\end{array}$ & $\begin{array}{c}2 \\
(6 \%)\end{array}$ & $\begin{array}{c}1 \\
(3 \%)\end{array}$ & $\begin{array}{c}0 \\
(0 \%)\end{array}$ & $\begin{array}{c}15 \\
(47 \%)\end{array}$ & $\begin{array}{c}7 \\
(22 \%)\end{array}$ & $\begin{array}{c}2 \\
(6 \%)\end{array}$ & $\begin{array}{c}0 \\
(0 \%)\end{array}$ & $\begin{array}{c}3 \\
(9 \%)\end{array}$ \\
\hline Misc. \& Spam & $\begin{array}{c}0 \\
(0 \%)\end{array}$ & $\begin{array}{c}0 \\
(0 \%)\end{array}$ & $\begin{array}{c}0 \\
(0 \%)\end{array}$ & $\begin{array}{c}0 \\
(0 \%)\end{array}$ & $\begin{array}{c}0 \\
(0 \%)\end{array}$ & $\begin{array}{c}0 \\
(0 \%)\end{array}$ & $\begin{array}{c}0 \\
(0 \%)\end{array}$ & $\begin{array}{c}0 \\
(0 \%)\end{array}$ & $\begin{array}{c}0 \\
(0 \%)\end{array}$ \\
\hline
\end{tabular}

Note: Number of images in each sample, followed by percentages of all images in the relevant mode. 
First, anti-European visuals, populist anti-elite messages, and to a lesser extent extremist content around religion, were shared in substantial amounts ahead of the elections. However, this content was largely disjointed from the mainstream conversation about the election on social media and confined to critical discussions of the European project. Experts had expressed concerns about the spread of extremist propaganda and other forms of social media manipulation ahead of the vote, notably around questions of immigration (Dennison \& Zerka, 2019). Contrary to these expectations, our data shows that extremist messaging predominately revolved around anti-Semitic tropes and pointed criticism of the purported Islamization of Europe.

Second, political humor emerged through our analysis as a popular vessel for Eurosceptic and anti-elite messaging in social media discourse, especially in the contentious conversation surrounding EU membership. Here, humorous visuals in the form memes, cartoons, and drawings, were predominantly mobilized to make ad populum arguments, attack political and economic elites, and to a lesser extent relay extremist viewpoints. These findings echo scholarship that flagged online political humor as a 'pipeline' to radicalization and extremism (Munn, 2019; Phillips \& Milner, 2017). Several scholars also point out that memes, in-jokes, and political trolling successfully mobilize user and algorithmic attention (Marwick \& Lewis, 2017; Wu, 2017)

Third, at odds with growing concerns surrounding the credibility and quality of political content circulating on social media, our data reveals that official campaign communication from candidates and political parties drove the largest proportion of visual traffic, both in the mainstream conversation and in the conversation specifically related to leaving the EU. This evidences the strong impact that traditional political actors continue to have on public conversations around elections and on the visual content that users encounter online. Traditional forms of political visuals like candidate posters and brochures, or official photographs from the campaign trail were widely shared on Twitter ahead of the vote. Likewise, material from non-party campaigners and 'satellite' (Dommett \& Temple, 2018) issue groups prevailed among Twitter users, embracing novel forms of online political expression, such as annotated screenshots and remixed media, to campaign in support or opposition to the EU as a single issue.

Our study presents several limitations that highlight the need for further research. The first and most evident one is the focus on a single platform, Twitter. While Twitter remains a prime arena for political communication-favored by a wide range of political actors-electioneering typically takes place across several social media platforms. Future research should therefore investigate how the framework developed here applies to more visual-centric platforms and their unique affordances. Furthermore, by opting for topicbased sampling, we are necessarily restricted in the kind of claims we can make with respect to the political actors behind these visuals. It will therefore be valuable for future work to investigate how visuals are mobilized by party actors as compared to private citizens through actor-based sampling for instance. Lastly, by grounding our analysis in real-time social media data our findings are specific to both the temporal and socio-technical contexts in which they were collected. Studying visual information on social media is, finally, an inherently versatile exercise that must consider the multifaceted and changing nature of visuals as they develop over time. An interesting area for future work, in this respect, will be to further explore the link between the visual and textual elements of social media images as they are assembled and reworked through memetic practice, for example, to move towards more multi-modal understandings of platform vernaculars (Pearce et al., 2020). While there are many ways of analyzing visual content and our approach does not purport to be exhaustive, our analysis nonetheless provides a robust and situated look at visual political content shared across multiple language spheres. Rigorous classifications and thematic analyses of visual social media are not only critical for assessing the qualities and integrity of online political discourse, but also for bringing forward evidence-based policy and platform recommendations to effectively protect democratic freedoms online.

\section{Acknowledgments}

The authors gratefully acknowledge the support of the European Research Council for the project 'Computational Propaganda: Investigating the Impact of Algorithms and Bots on Political Discourse in Europe,' Proposal 648311, 2015-2020, Philip N. Howard, Principal Investigator. Project activities were approved by the University of Oxford's Research Ethics Committee, CUREC OII C1A 15-044. We are grateful to Civitates and the Omidyar Network for supporting our research in Europe. Any opinions, findings, conclusions or recommendations expressed in this material are those of the authors and do not necessarily reflect the views of the University of Oxford or our funders. We are also grateful to Samuelle Chinellato, Didac Fabregas, Freja Hedman, Tomasz Hollanek, Juan Lopez Martin, Karolina Partyga and Francesco Pierri for their contributions to this work.

\section{Conflict of Interests}

The author declares no conflict of interests.

\section{Supplementary Material}

Supplementary material for this article is available online in the format provided by the author. 


\section{References}

Barry, A. M. (2005). Perception theory. In S. Josephson, J. Kelly, \& K. Smith (Eds.), Handbook of visual communication: Theory, methods, and media (pp. 45-63). Abingdon: Routledge.

Bell, P. (2004). Content analysis of visual images. In T. Van Leeuwen \& C. Jewitt (Eds.), The handbook of visual analysis (pp. 10-34). London: SAGE.

Birdsell, D. S., \& Groarke, L. (2007). Outlines of a theory of visual argument. Argumentation and Advocacy, 43(3/4), 103-113. https://doi.org/10.1080/ 00028533.2007 .11821666

Blair, A. (2004). The rhetoric of visual arguments. In M. H. Helmers \& C. Hill (Eds.), Defining visual rhetorics (pp. 41-61). Mahwah, NJ: Lawrence Erlbaum.

Bradshaw, S., \& Howard, P. N. (2019). The global disinformation order 2019 global inventory of organised social media manipulation (Working Paper 2019.2). Oxford: Project on Computational Propaganda.

Braun, V., \& Clarke, V. (2006). Using thematic analysis in psychology. Qualitative Research in Psychology, 3(2), 77-101. https://doi.org/10.1191/ 1478088706qp063oa

Burgess, J., \& Bruns, A. (2012). Twitter archives and the challenges of "big social data" for media and communication research. M/C Journal, 15(5). https://doi. org/10.5204/mcj.561

Caiani, M., \& Pavan, E. (2017). "Inconvenient solidarities": Extreme-right online networks and the construction of a critical frame against Europe. In A. Grimmel \& S. M. Giang (Eds.), Solidarity in the European Union: A fundamental value in crisis (pp. 145-160). Cham: Springer International Publishing.

Cámara Castillo, L. (2019). Advertising the European identity: Instagram analysis on the visual selfpresentation of the European Parliament and the European Commission (Master thesis). University of Helsinki, Helsinki, Finland. Retrieved from https://helda.helsinki.fi/handle/10138/302878

Cerulus, L. (2019, January 16). Europe's most hackable election. POLITICO. Retrieved from https:// www.politico.eu/article/europe-most-hackableelection-voter-security-catalonia-europeanparliament-disinformation

Chadwick, A. (2013). The hybrid media system: Politics and power. Oxford: Oxford University Press.

Clarke, V., Braun, V., \& Hayfield, N. (2015). Thematic analysis. In J. A. Smith (Ed.), Qualitative psychology: A practical guide to research methods (pp. 222-248). London: SAGE.

Czuperski, M., \& Nimmo, B. (2017). \#ElectionWatch: Germany's AfD utilizes fake imagery ahead of election. DFRLab. Retrieved from https://medium.com/ dfrlab/electionwatch-germanys-afd-utilizes-fakeimagery-ahead-of-election-1fa1818ea82a

de Vreese, C. H. (2005). News framing: Theory and typology. Information Design Journal + Document Design,
13(1), 51-62.

Dean, J. (2019). Sorted for memes and Gifs: Visual media and everyday digital politics. Political Studies Review, 17(3), 255-266. https://doi.org/10.1177/ 1478929918807483

Dennison, S., \& Zerka, P. (2019). The 2019 European election: How anti-Europeans plan to wreck Europe and what can be done to stop it. European Council on Foreign Relations. Retrieved from https://www.ecfr.eu/ specials/scorecard/the_2019_European_election

Dommett, K., \& Temple, L. (2018). Digital campaigning: The rise of Facebook and satellite campaigns. Parliamentary Affairs, 71(1), 189-202. https://doi.org/ 10.1093/pa/gsx056

Edwards, A. (2006). ICT strategies of democratic intermediaries: A view on the political system in the digital age. Information Polity, 11(2). https://dl.acm.org/ doi/10.5555/1412569.1412572

European Parliament. (2019). The voting system. European Parliament. Retrieved from http://www. europarl.europa.eu/unitedkingdom/en/europeanelections/european_elections/the_voting_ system.html

Fahmy, S., Bock, M. A., \& Wanta, W. (2014). Visual communication theory and research. New York, NY: Palgrave Macmillan.

Freelon, D. (2018). Computational research in the postAPI age. Political Communication, 35(4), 665-668. https://doi.org/10.1080/10584609.2018.1477506

Gillepsie, T. (2018). Custodians of the Internet: Platforms, content moderation, and the hidden decisions that shape social media. New Haven, CT: Yale University Press.

Graber, D. A. (2012). Processing politics: Learning from television in the Internet age. Chicago, IL: University of Chicago Press.

Guerra, S., \& Serricchio, F. (2014). Identity and economic rationality: Explaining attitudes towards the EIU in a time of crisis. In B. M. Stefanova (Ed.), The European Union beyond the crisis: Evolving governance, contested policies, and disenchanted publics (pp. 269-294). London: Lexington Books.

Gutterman, R. S. (2018). Ballot selfies: New political speech in search of first amendment protection in social media. Wake Forest Journal of Law \& Policy, 8(2), 211-258.

Guy, H. (2017, October 17). Why we need to understand misinformation through visuals. First Draft News. Retrieved from https://firstdraftnews.org:443/ latest/understanding-visual-misinfo

Hemsley, J., \& Mason, R. M. (2013). Knowledge and knowledge management in the social media age. Journal of Organizational Computing and Electronic Commerce, 23(1/2), 138-167. https://doi.org/ 10.1080/10919392.2013.748614

Hemsley, J., \& Snyder, J. (2018). Dimensions of visual misinformation in the emerging media landscape. In B. G. Southwell, E. A. Thorson, \& L. Sheble (Eds.), Misinfor- 
mation and mass audiences (pp. 91-109). Austin, TX: University of Texas Press.

Highfield, T., \& Leaver, T. (2016). Instagrammatics and digital methods: Studying visual social media, from selfies and Gifs to memes and emoji. Communication Research and Practice, 2(1), 47-62. https://doi.org/ 10.1080/22041451.2016.1155332

Howard, P. N., \& Hussain, M. M. (2013). Democracy's fourth wave? Digital media and the Arab Spring. Oxford: Oxford University Press.

Jungherr, A., Posegga, O., \& An, J. (2019). Discursive power in contemporary media systems: A comparative framework. The International Journal of Press/Politics, 24(4), 404-425. https://doi.org/ $10.1177 / 1940161219841543$

Karpf, D. (2012). The moveon effect: The unexpected transformation of American political advocacy. Oxford: Oxford University Press.

Kharroub, T., \& Bas, O. (2015). Social media and protests: An examination of Twitter images of the 2011 Egyptian revolution. New Media \& Society. https://doi. org/10.1177/1461444815571914

Kitschelt, H. (2006). Movement parties. In R. Katz \& W. Crotty (Eds.), Handbook of party politics (pp. 278-290). London: SAGE.

Klein, O. (2019). LOLitics: The content and impact of Dutch populist Internet memes. Unpublished manuscript. Retrieved from https://ssrn.com/ abstract $=3371224$

Larsson, A. O., \& Moe, H. (2012). Studying political microblogging: Twitter users in the 2010 Swedish election campaign. New Media \& Society, 14(5), 729-747. https://doi.org/10.1177/1461444811422 894

Lilleker, D. G., Tenscher, J., \& Štětka, V. (2015). Towards hypermedia campaigning? Perceptions of new media's importance for campaigning by party strategists in comparative perspective. Information, Communication \& Society, 18(7), 747-765. https://doi. org/10.1080/1369118X.2014.993679

Lyons, K. (2019, October 30). Bring it on memes and "guy ropes of self-doubt": The first UK General Election ads. The Guardian. Retrieved from https:// www.theguardian.com/politics/2019/oct/30/bringit-on-memes-and-guy-ropes-of-self-doubt-the-firstuk-general-election-ads

Marchal, N., Kollanyi, B., Howard, P. N., \& Neudert, L.-M. (2019). Junk news during the 2019 EU parliamentary elections: Lessons from a seven-language study of Twitter and Facebook (Data Memo 2019. 3). Oxford: Project on Computational Propaganda.

Margetts, H., John, P., Hale, S., \& Yasseri, T. (2015). Political turbulence: How social media shape collective action. Princeton, NJ: Princeton University Press.

Marwick, A., \& boyd, d. (2011). "I tweet honestly, I tweet passionately": Twitter users, context collapse, and the imagined audience. New Media \& Society, 13(1), 114-133. https://doi.org/10.1177/
1461444810365313

Marwick, A., \& Lewis, R. (2017). Media manipulation and disinformation online. Data \& Society. Retrieved from https://datasociety.net/output/mediamanipulation-and-disinfo-online

Meeker, M. (2019). Internet trends 2019. Bond. Retrieved from https://www.bondcap.com/report/ itr19

Morstatter, F., Pfeffer, J., Liu, H., \& Carley, K. M. (2013). Is the sample good enough? Comparing data from Twitter's streaming API with Twitter's firehose. ArXiv. Retrieved from http://arxiv.org/abs/1306.5204

Munn, L. (2019). Alt-right pipeline: Individual journeys to extremism online. First Monday. https://doi.org/ 10.5210/fm.v24i6.10108

Neudert, L.-M., Howard, P., \& Kollanyi, B. (2019). Sourcing and automation of political news and information during three European elections. Social Media + Society, 5(3). https://doi.org/10.1177/ 2056305119863147

Neuendorf, K. A. (2019). Content analysis and thematic analysis. In P. Brough (Ed.), Research methods for applied psychologists: Design, analysis and reporting (pp. 211-223). New York, NY: Routledge.

Newhagen, J. E. (1998). TV news images that induce anger, fear, and disgust: Effects on approachavoidance and memory. Journal of Broadcasting \& Electronic Media, 42(2), 265-276. https://doi.org/ 10.1080/08838159809364448

Nightingale, S. J., Wade, K. A., \& Watson, D. G. (2017). Can people identify original and manipulated photos of real-world scenes? Cognitive Research: Principles and Implications, 2(1). https://doi.org/10.1186/ s41235-017-0067-2

Pearce, W., Özkula, S. M., Greene, A. K., Teeling, L., Bansard, J. S., Omena, J. J., \& Rabello, E. T. (2020). Visual cross-platform analysis: Digital methods to research social media images. Information, Communication \& Society, 23(2), 161-180. https://doi.org/ 10.1080/1369118X.2018.1486871

Phillips, W., \& Milner, R. M. (2017). The ambivalent Internet: Mischief, oddity, and antagonism online. Cambridge: Polity.

Reading, A. (2011). The London bombings: Mobile witnessing, mortal bodies and globital time. Memory Studies. https://doi.org/10.1177/1750698011 402672

Rohlinger, D. A. (2019). New media and society. New York, NY: New York University Press.

Rose, G. (2012). Visual methodologies. London: SAGE.

Schill, D. (2012). The visual image and the political image: A review of visual communication research in the field of political communication. Review of Communication, 12(2), 118-142. https://doi.org/10.1080/ 15358593.2011.653504

Segesten, A., \& Bossetta, M. (2017). Sharing is caring: Labour supporters use of social media \#ge2017. Election Analysis. http://www.electionanalysis.uk/ 
uk-election-analysis-2017/section-5-the-digitalcampaign/sharing-is-caring-labour-supporters-useof-social-media-ge2017

Senft, T. M., \& Baym, N. (2015). What does the selfie say? Investigating a global phenomenon: Introduction. International Journal of Communication, 9, 1588-1606.

Seo, H. (2014). Visual propaganda in the age of social media: An empirical analysis of Twitter images during the 2012 Israeli-Hamas conflict. Visual Communication Quarterly, 21(3), 150-161.

Sorokowska, A., Oleszkiewicz, A., Frackowiak, T., Pisanski, K., Chmiel, A., \& Sorokowski, P. (2016). Selfies and personality: Who posts self-portrait photographs? Personality and Individual Differences, 90, 119-123. https://doi.org/10.1016/j.paid.2015.10.037

Stokel-Walker, C. (2019, January 10). The EU doesn't really have a plan to stop its elections being hacked. Wired UK. Retrieved from https://www.wired.co.uk/ article/eu-parliament-elections-hacking

Tay, G. (2015). Binders full of LOLitics: Political humour, internet memes, and play in the 2012 US Presidential Election (and beyond). European Journal of Humour Research, 2(4). http://dx.doi.org/10.7592/EJHR2014. 2.4.tay

Thomson, T. J., \& Greenwood, K. (2020). Profile pictures across platforms. In S. Josephson, J. D. Kelly, \& K. Smith (Eds.), Handbook of visual communication (1st ed., pp. 349-363). London: Routledge.

Weller, K., Bruns, A., Burgess, J., Mahrt, M., \& Puschmann, C. (2014). Twitter and society. New York, NY: Peter Lang Publishing.

Woolley, S. C., \& Howard, P. N. (Eds.). (2018). Computational propaganda: Political parties, politicians, and political manipulation on social media. Oxford: Oxford University Press.

$\mathrm{Wu}, \mathrm{T}$. (2017). The attention merchants: The epic struggle to get inside our heads. New York: Knopf.

\section{About the Authors}

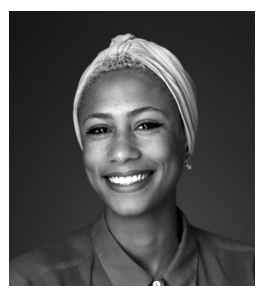

Nahema Marchal is a Doctoral Candidate at the Oxford Internet Institute, University of Oxford, where her research focuses on the relationship between social media and political polarization. She is also a Researcher at the Computational Propaganda Project. Her other research interests include Internet regulation and governance, and the implications of digital technologies for public life.

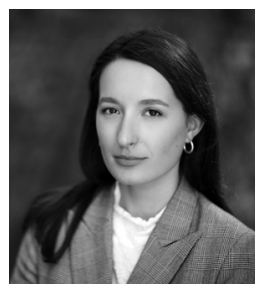

Lisa-Maria Neudert is a Doctoral Candidate at the Oxford Internet Institute and a Core Researcher at the Computational Propaganda Project, where her work is located at the nexus of political communication, technology studies and governance. Her current research is looking into the public and private governance of policy issues surrounding disinformation through governments and social media platforms.

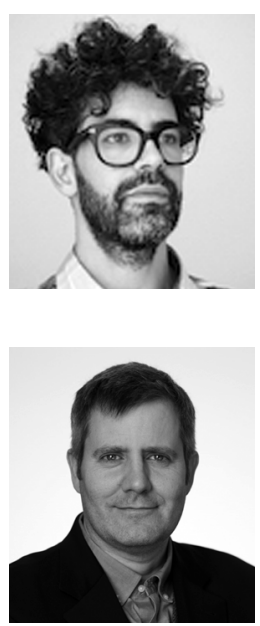

Bence Kollanyi is a Doctoral Candidate in Sociology at the Corvinus University of Budapest where his research focuses on the automation of social media accounts, including the development and the deployment of open-source Twitter bots. At the Computational Propaganda Project at the Oxford Internet Institute, Bence is responsible for collecting and analysing data from various social media platforms.

Philip N. Howard is a Statutory Professor of Internet Studies at the Oxford Internet Institute and a Professorial Fellow at Balliol College at the University of Oxford. He has published eight books and over 120 academic articles, book chapters, conference papers, and commentary essays on information technology, international affairs and public life. He is the author, most recently, of Lie Machines: How to Save Democracy from Troll Armies, Deceitful Robots, Junk News Operations, and Political Operatives. 